\title{
The Effectiveness of In-Person versus Online Instruction in the Pre-service Teacher Preparation Programme
}

\begin{abstract}
In reference to the reflective nature of the methodological design of the current pre-service English teacher education program at the Faculty of Arts, University of Ljubljana, considerable challenges related to teacher-education were noted during the emergency online switch. For this reason, the theory/practice connections, typically strengthened via the practical, experiential and reflective components of university teacher-education programs, were put to the test. The research is aimed at identifying the challenges of the online switch and focuses on comparison of the effectiveness of in-person versus online instruction in the preservice English teacher preparation program. The research questions seek to examine whether teacher-training sessions online are more demanding and challenging, and potentially less effective (as perceived by the respondents), compared to the in-person teacher-training practices. The study results offer a valuable insight into the teacher-trainees' perceptions of the challenges and effectiveness of the online English teacher-training course implementation in comparison with the in-person mode.
\end{abstract}

Keywords: pre-service English teacher education, reflective model, pandemic, in-person instruction, online teaching

\section{Primerjalna študija učinkovitosti spletne in "v živo« izvedbe začetnega izobraževanja učiteljev angleščine}

\section{IZVLEČEK}

Glede na reflektivno naravo metodološke zasnove programov začetnega izobraževanja učiteljev angleščine na Filozofski fakulteti Univerze v Ljubljani je prehod izobraževanja učiteljev iz fizičnih predavalnic v digitalno okolje - tako imenovani online "switch" - spremljala vrsta izzivov. Zaradi tega so se povezovanja teorije s prakso, ki se tipično krepijo skozi praktične, izkustvene in reflektivne sestavine izobraževanja učiteljev na univerzitetni ravni, tokrat znašla na preizkušnji. Pričujoča raziskava se osredinja na opredelitev glavnih izzivov prehoda izobraževalnega procesa bodočih učiteljev angleščine $\mathrm{v}$ digitalno okolje in na primerjavo učinkovitosti obeh modelov poučevanja - spletno in "v živo«. Preverja, kateri izmed dveh načinov izvajanja izobraževanja učiteljev se po mnenju študentov pedagoških programov anglistike izkazuje za bolj zahtevnega in morda posledično manj učinkovitega. Rezultati raziskave ponujajo dragocen vpogled v njihovo percepcijo izzivov in učinkovitosti izvajanja programa izobraževanja učiteljev angleščine v digitalnem okolju v primerjavi z izvedbo »v živo«.

Ključne besede: začetno izobraževanje učiteljev angleščine, reflektivni model, pandemija, poučevanje "v živo«, spletno poučevanje 


\section{Introduction}

The shutdown of universities and schools in Slovenia, due to the COVID-19 pandemic, came in mid-March 2020. During the academic year 2020/21, the restrictions imposed regionally or nationally varied, depending on the COVID-19 situation, with primary and secondary schools being both on- and offline, then moving to a hybrid model, to finally reopening in May 2021 (Krek 2021; Ritchie et al. 2020). The universities remained online throughout the academic year. So, there has been variance in the disruption experienced by initial teacher training (henceforth referred to as ITT) trainees during the academic year 2020/21 regarding their final practicum or school placements, whereas the university-based teacher training program remained online throughout the year. This research focuses on the challenges this posed for both trainees and teacher educators.

\subsection{The Initial Teacher Training Design}

The context framing this research is the official route into teaching established by the Bologna Reform in Higher Education in Slovenia. The Faculty of Arts adopted the so-called twocycle degree structure, i.e., a 3-year Bachelor's/Undergraduate Level, plus a 2-year Master's/ Graduate Level. In this two-cycle degree structure, the first three years of undergraduate studies are, in the case of future teachers of English, devoted entirely to subject-specific courses relating to linguistics and literature. The whole teacher preparation program is placed within the second cycle, i.e., at Master's Level, and within what we refer to as the Pedagogical Module. Students at MA level can opt to follow either the non-pedagogical (i.e., omitting all teacher-training courses) or pedagogical route, the latter being the only route into teaching.

TABLE I. Subject-specific teacher training curriculum.

\begin{tabular}{|c|c|c|}
\hline & Contact Hours & ECTS \\
\hline \multicolumn{3}{|l|}{ Year 1} \\
\hline The Fundamentals of ELT Methodology & 150 & 8 \\
\hline Methods and Techniques of Teaching English & 60 & 7 \\
\hline Teaching Practice for English Teachers (practicum) & 30 & 2 \\
\hline \multicolumn{3}{|l|}{ Year 2} \\
\hline Programs and Coursebooks in ELT & 45 & 4 \\
\hline Testing in ELT & 30 & 3 \\
\hline Scientific Research Work in Foreign Language Pedagogy & 30 & 3 \\
\hline Elective courses (trainee chooses 2 out of 3 ): & $30+30$ & $3+3$ \\
\hline Teaching English for Specific Purposes & & \\
\hline Teaching English Across Age Groups & & \\
\hline Trends in ELT & & \\
\hline Teaching Practice for English Teachers (practicum) & 30 & 4 \\
\hline Total & 435 & 37 \\
\hline
\end{tabular}

The current teacher preparation program provided by the Faculty of Arts, University of Ljubljana, is a mixture of both consecutive and concurrent models, because trainees enrol 
into the MA program with a BA (i.e., subject-specialist) degree, but continue to study, during both MA Level years, both the academic subjects and educational and pedagogical studies in a 1:1 ratio. The scope of the Master's degree curriculum is 120 ECTS credits - 60 credit points of academic subjects, and 60 credit points of the educational and pedagogical studies. Quantitatively, the pre-service teacher training program is in fact a one-year post-graduate program spreading over two years of MA Level.

The pedagogical module consists of two parts: (a) general educational and pedagogical studies, and (b) subject-specific teacher training courses. The scope of the general educational and pedagogical studies is the same for all departments at the Faculty of Arts that provide a pedagogical route of studies.

The scope of the subject-specific teacher training courses at the Department of English, Faculty of Arts, is presented in Table 1.

\subsection{The COVID-19 Lockdown Effects on ITT}

Before we move on to describe the situation that happened in March 2020 when, as a direct result of the COVID-19 pandemic, all universities and schools in Slovenia shut down and transferred teaching online, we need to highlight the main methodological and 'philosophical' design of the pre-service teacher education program to see how it was affected by this sudden change of teaching. The methodology of the pre-service teacher education program stresses the importance of involving the student teachers in the instruction through hands-on activities, class discussions, pair work, brainstorming sessions, etc. In other words - the program is based on the so-called reflection-oriented approach to teacher training. Such methodology, besides giving trainees the opportunity to examine their attitudes, beliefs and assumptions, also echoes classroom practice much more closely. As we are discussing the methodological design of the program, we will be interested in whether the imposed online teaching mode spelled a return to a more traditional way of teaching. In other words, we will try to show whether giving teacher training sessions online is more demanding and challenging, and potentially less effective, or not.

\section{Strengthening Theory/Practice Connections via the Methodological Design of the Pre-service Teacher Preparation Program}

Within pre-service teacher education programs, the so-called 'theory/practice divide' and the importance of the practicum (or placement) in schools have been much debated (Malderez and Bodoczky 1999; Gebhard 2009; Kidd and Murray 2020). The practicum is usually widely recognized, as it represents the central link between theory and practice - it is only here that the principle of "theorising practice or practising theory" can be applied (Kumaravadivelu 1999, 33). In other words, it is during the practicum that trainees acquire the skills to transfer knowledge of pedagogy to practice. Although the practicum is, without doubt, the strongest connection between practice and theory (i.e., academic knowledge at the university), it is not the only one. Other solutions to strengthening theory/practice connections include 
increasing the practical, skills-based, experiential and reflective components of university teacher education programs (Kidd and Murray 2020, 544). In the remainder of this paper, the theory/practice connections will be highlighted and researched on the basis of one subject-specific course - The Fundamentals of ELT Methodology (see Table 1) - comparing its in-person and online execution, respectively.

Various models of teacher learning have been suggested. The three main ones, as described in Wallace (1991), are as follows: (1) the craft model, (2) the applied science model, and (3) the reflective model. The craft model typically involves pre-service teachers working alongside experienced masters, following their instructions and advice, and learning by imitating. In this model, the wisdom of the profession resides in an experienced professional practitioner: someone who is an expert in the practice of the 'craft'. Or, as Roberts (1998) puts it, preservice teachers in the craft model are viewed essentially as input-output systems.

The applied science model is the traditional and probably still the most prevalent model underlying most teacher-training education programs (Wallace 1991). In this model, theoretical/scientific knowledge is conveyed to pre-service teachers by experts, and then it is up to the trainees to put this knowledge into practice. It is obvious, then, that a teacher's expertise will be mostly developed on the job. This model clearly shows the tendency for the experts to be well removed from the day-to-day working scene, and reveals a fairly clear divide between the 'thinkers' and 'doers'.

Since the 1970s, there has been a marked shift in our understanding of what we mean by teacher preparation. Since then, several developments have significantly shaped the way second language teacher education is currently conceptualized (Burns and Richards 2009), of which the most important are changes in the knowledge base of language teaching and a re-orientation of our perspectives on pre-service teachers (Skela 2019). Pre-service teachers started to be viewed as constructivists who craft personal constructions of their professional contexts, and as social beings whose professional role is shaped by social rules, group identity, occupational culture, and teacher development in the context of school (Roberts 1998). Roberts suggests that "behavioural and humanistic perspectives throw useful but only partial light on teacher learning", and that "a synthesis of constructivist and social perspectives, a broadly social constructivist view, provides the most helpful and appropriate general framework for teacher education design" (Roberts 1998, 13). Such a synthesis led to the development of the reflective model of teacher education.

The reflective model is trainee-centred. It assigns great importance to teacher cognition (i.e., what teachers think, know, and believe; Borg 2006, 2009) and seeks to establish solid connections between theory (i.e., both personal small $t$ theories, and the capital $T$ Theory) and classroom practices. It includes two kinds of knowledge development: (a) received knowledge (i.e., external input coming from scholarly sources, the collective theoretical knowledge of the profession or the capital TTheory), and (b) experiential knowledge. The trainee will develop experiential knowledge by teaching or observing lessons, or recalling past experience; then reflecting, alone or in discussion with others, in order to work out theories about teaching; then trying these out again in practice. Such a 'reflective cycle' aims for continuous improvement and development of personal theories in action (Ur 1996, 5). 
These models are, of course, nothing but archetypes, providing only very general design principles for a teacher education program. Probably all three models have some truth in them. First, there is a lot to be learnt from 'master teachers' (as in the craft model); second, there is a lot to be learnt from experts and from reading scholarly sources (as in the applied science model); and finally, promoting the active engagement of student teachers in opportunities to learn through doing and reflection probably does help them integrate these external sources of input into their own reflection-based theories (as in the reflective model). Clearly, all three models of teacher learning have their advantages and disadvantages, as none on its own can really cover the complexity of language teacher education. They provide, in various combinations, the theoretical basis for teacher education design, but they can, however, become problematic if applied at their extremes. However, as the models are not mutually exclusive they can be intertwined and combined into an 'eclectic' approach to teacher development, following an inductive practice-reflection-theory cycle (Chaves and Guapacha 2016, 75, 81).

The question all teacher educators have to face is how teachers learn most effectively, and how this learning can be integrated into a formal course of study. The design of any teacher education program is often based on both objective, or contextual, and personal, or intuitive, principles adhered to by teacher educators. In our case, the authors of this article, both being pre-service teacher educators, have chosen to base the pre-service teacher education programme to a large extent on the 'reflective model'. Our decision is based on two sources of knowledge - first, our personal professional practice as teacher educators, and second, the bulk of the literature and research examining the nature of (language) teacher development, with a special emphasis on the reflective model (Freeman and Cornwell 1993; Dufeu 1994; Richards and Lockhart 1994; Medgyes and Malderez 1996; Nunan and Lamb 1996; Richards 1998; Roberts 1998; Gebhard and Oprandy 1999; Malderez and Bodoczky 1999; TrappesLomax and McGrath 1999; Moon 2004; Malderez and Wedell 2007; Wright and Bolitho 2007; Dymoke and Harrison 2008; Burns and Richards 2009; Borg 2006, 2009, etc.).

We believe that recognizing the legitimacy of teacher-learners' implicit personal theories and the role of prior (experiential) knowledge (Borg 2006, 2009) calls for the kind of teacher education pedagogy/methodology that emphasizes exploration and experimentation, risk taking and cooperation, balancing input and reflection, using what trainees bring and know, and increasing their autonomy (Freeman and Cornwell 1993, xiii-xiv). Such a reflective teaching methodology resists the assumption that people will learn to teach just by being told what to do or how to do it. Instead, it is based on the educational philosophy of constructivism which claims that knowledge is actively constructed and not passively received.

If we consider that the professional development of language teachers should involve the various above-mentioned perspectives, it seems only logical to incorporate explicit reflective techniques into a teacher education program. A training framework as a bridge to reflective practice typically contains activities such as the teaching practicum, teaching practice portfolios, supervision and the supervisory dialogue, reflective demonstration (follow me!), micro-teaching, loop input (hall of mirrors), journal and diary keeping, peer observation, action research, study groups, self-development activities, and others (Wallace 1999, 184-86). 
What these instructional practices have in common is that they see teacher learning as the theorization of practice (i.e., knowledge construction); in other words, making visible the student-teacher's beliefs about teaching and the nature of practitioner knowledge, and thus providing the means by which such knowledge can be elaborated, understood, reviewed, and reorganized (Burns and Richards 2009).

Despite many pedagogical and institutional barriers to devising and implementing 'reflective practice' in pre-service training (Wallace 1999, 184; Cornford 2002; Russell 2005; Kuswandono 2012; Skela 2019, 27-29), it seems to us that a broadly reflective model of learning teaching still provides the most helpful and appropriate general framework for teacher education design. There is obviously still a lot of work to be done to establish a satisfactory framework for teacher education, but it seems that reflective teaching is here to stay as one of the most flexible and useful teacher training designs that we have available to bridge the gap between the theory and practice of ELT methodology (Skela 2019). After all, over the last two decades studies on reflective practice in the professional development of teachers have continued to attract researchers' attention (e.g., Griffiths 2000; Kuit, Reay, and Freeman 2001; Cornford 2002; Ward and McCotter 2004; Russell 2005; Akbari 2007; Lupinski et al. 2012; Sellars 2012; Colomer et al. 2013; Mathew et al. 2017, etc.).

No pre-service model, however good, can produce fully competent teachers. But what it can and probably should do is "to lay the seeds of further development" (Ur 1996, 8) by providing trainees with opportunities to develop reasoning and reflective skills, tools and processes for continuing their own learning of teaching (Malderez and Bodoczky 1999, 13). As such, a pre-service course "should be seen as the beginning of a process, not a complete process in itself: participants should be encouraged to develop habits of learning that will carry through into later practice and continue for their entire professional lives" (Ur 1996, 8).

\subsection{The Methodological Design of The Fundamentals of ELT Methodology Course}

The Fundamentals of ELT Methodology, chosen for our research focus, is a 'big', whole-year course with an extensive syllabus ranging from very theoretical to very practical topics (for example, second language acquisition theories vs. techniques of presenting vocabulary). With its scope and content, it lays the foundation for all of the other subject-specific courses in the pre-service teacher education program.

Clearly, with such a wide-ranging and varied syllabus, there will be topics that lend themselves more easily to 'reflective' teaching than others. The way we go about handling different types of course input is by trying to balance the two kinds of knowledge development, typically enshrined in the reflective model - received knowledge (i.e., external input coming from scholarly sources), and experiential knowledge. Both types of input are tackled by means of different teaching modes (listed in the first question in the questionnaire), or 'process options/types' (Woodward 1992). Teaching modes such as lecturing, discussion and brainstorming are simply different ways of tackling input, and they are separate from content. Lecturing, for example, is a 'process option' which can convey many different 
kinds of content, and a brainstorm can be about responses to ways of indicating language errors, or anything else (Woodward 1992, 3). According to Woodward (1992, 3), the term process, or process option, "denotes how encounters can be set up so that knowledge, skill or insight of trainees, trainers and others can be communicated between them." The process options, or teaching modes, are thus "about ways of enabling, sharing, eliciting, encouraging, questioning, responding, enriching and developing, as well as about more didactic 'transmission' actions such as telling, helping and informing" (1992, 3). Regardless of content, a teacher training course could stick totally to one process type (or teaching mode), for example, the traditional lecture. But if we want a lecture to involve sharing, interacting, discussing or challenging, then we will need to change some steps in the normal lecture process.

On The Fundamentals of ELT Methodology course a wide repertoire of process options is used, and thus input is tackled in different ways. In this way, we believe, trainees with different learning styles are better served. Hearing and reading may be enough for some trainees, but others will need to participate, talk, draw, visualize, experience, watch, reflect, and so on, in order to truly take in the new ideas offered to them. Over the years, the course has been shaped and re-shaped by our personal experience and by thought and input from outside, resulting in the course being based on some sort of a broadly reflective, eclectic and inductive methodological approach (see Chaves and Guapacha 2016). The course being 'inductive' means starting sessions with practical demonstrations followed by reflection and ending with theory, if necessary. By a cross-fertilisation between teaching modes and content, we are trying to integrate practical and theoretical foundations. The methodology of the course is to a large extent based on many versatile resource books containing a comprehensive range of tasks, such as Woodward (1991, 1992), Freeman and Cornwell (1993), Parrott (1993), Balloch (1996), Tanner and Green (1998), James (2001), Thaine (2010), etc. Such methodology, we believe, promotes participation, discussion, reflection, and class work, provides and connects theory and practice, includes varied activities, is student-centred, active and experiential (i.e., it checks for prior knowledge and misconceptions), considers different learning styles, and provides trainees with sufficient scaffolding to anchor the learning.

\section{Research Questions}

By providing an insight into the reflective nature of the methodological design of the current pre-service teacher education program at the Faculty of Arts, University of Ljubljana, we wanted to emphasize the considerable challenges related to online teacher education. Because of the legacy of knowledge-transmission, which is very pervasive and embedded in most institutions that prepare teachers, implementing a reflective model of learning teaching in pre-service teacher education is very difficult even in normal circumstances, and all the more so when it comes to online teacher education. As pointed out initially, theory/practice connections can be strengthened via the practical, experiential and reflective components of university teacher education programs, and primarily via the practicum. With this, we move on to the research part to show what were the challenges related to the effectiveness of inperson versus online instruction in the pre-service teacher preparation program, as perceived by the teacher-trainees acting as respondents in the study. 
Of the subject-specific teacher training courses shown in Table 1, our research focus has been narrowed down to a single course - The Fundamentals of ELT Methodology. The reason for this is at least twofold - one, it is, as the name suggests, a foundational and 'big' whole-year course with 150 contact hours and, two, it directly prepares students for the upcoming teaching practicum, including group observations/school visits. This study sought to examine whether giving teacher training sessions online is more demanding and challenging, and potentially less effective, or not. The research questions were as follows:

1. What are the challenges, related to online teacher-training and 'e-practicum'?

2. Is the online reflective pre-service teacher-training perceived by the respondents as effective (compared to those who experienced teacher-training courses in-person)?

3. In the context of the imposed online teaching mode, did the survey results spell a return to a more traditional way of teaching the university-based teacher preparation courses?

4. Were, as a result of this, the desired levels of learner engagement and outcomes achieved or not?

5. According to the survey results, were online lesson observations perceived by the respondents as effective?

There were some ethical considerations which shaped the way the research was conducted. Firstly, as the switch to working online happened practically overnight, it left little time for the instructors to adapt the course content for the digital environment, which might have affected the research results. On the other hand, it also strengthens the results as the materials were only adjusted with regard to the technical aspects to make the format more appropriate for an online environment (such as preparation of the documents and related instructions for distance learning, moving the discussions online into forums and chatrooms, increasing the number of home assignments in place of classroom activities, and similar). Secondly, the comparison of the views of two different groups with regard to their impressions of two different modes of course implementation might represent a methodological constraint, but as the study focuses on the general satisfaction with the course implementation and as the students can only take the same course once, a comparison of the two modes in a single group of respondents was not an option at this point. The survey results are thus interpreted within the highlighted differences perceived by the two groups of respondents (such as in research questions 2 and 5 , for instance).

\section{Method}

The research was designed in two parts, involving two anonymous online surveys, intended for two different sets of respondents. The open-access online survey tool $1 \mathrm{ka}$ was used, available at https://www. $1 \mathrm{ka} . \mathrm{si} /$, to collect the responses to two sets of questions. The surveys were conducted in June 2021, with a sample of 49 respondents, spanning across two generations of MA students enrolled in the pre-service teacher preparation program at the Department of English, Faculty of Arts, University of Ljubljana.

The first part of the research was focused on gathering data on in-person instruction in the pre-service teacher preparation programme (hereafter referred to as the ODA course, which 
stands for Osnove didaktike angleščine - The Fundamentals of ELT Methodology), which had prior to the pandemic lockdown - in the fall semester of the academic year 20219/20 - been conducted entirely in a physical classroom. In the spring semester of the same academic year the instruction was transferred online, but it was predominantly implemented within the e-classroom digital environment, in the absence of virtual contact sessions. This group of respondents, therefore, experienced both in-person and online modes in the academic year 2019/20, although their online experience was not comparable to the Zoom instruction of the following academic year, with virtual contact sessions. The sample for this part of the research was 14 out of the expected 21 respondents, with the latter being the figure for the 2019/20 generation's enrolment.

The second part of the research was centred on collecting the data on the online ODA course, which took place during the entire academic year 2020/21. The course was conducted exclusively in the Zoom digital environment. The sample for this part of the research was 35 out of the expected 45 respondents, with the latter being the figure for the 2020/21 generation's enrolment.

The first 12 questions of the two surveys were identical. They focused on the teaching modes, the nature of instruction, balance between theory and practice, students' motivation levels, expectations for the course and the effectiveness of the instruction. The questions were formulated in various modes, where the respondents had to range their answers according to importance and level of appropriateness, or mark their value on a scale from completely agree to completely disagree (cf. Figures 1 and 2 below for more detailed information on the questionnaire).

In addition to the first 12 questions, the second survey consisted of another set of 17 questions, primarily targeting the respondents' issues with the online implementation of the course, such as technology-related issues, time management, interference from home environment, overall effectiveness of online instruction, as well as their general impressions of the online course instruction experience (cf. Figures 3 and 4 below for more detailed information on the second part of the questionnaire).

A 1-6 Likert scale was used for ranking the categories, offering options ranging from extremely satisfied to extremely dissatisfied. The 1-6 scale was specifically chosen because it pushes the respondents into making a choice, thus rendering the data collected more reliable. However, there is an ongoing Likert scale debate which, according to several sources (cf. Krosnick et al. (2002), Kulas et al. (2008 and 2009), and others), questions the 'reliability of data' argument for the 1-6 scale. The current research review suggests arguments in favour as well as against either option, and leaves the final decision governed by the researchers' focus and aims.

\section{Results and Discussion}

Figures 1-3 offer a comparison of the survey results for the first 12 questions. As the individual figures are featured side by side, the presentation also allows for a visual impression and assessment of the values. Figures 4-7 feature results for the second set of questions, intended for the online group only. 
In reference to the first question, targeted at accruing data on the teaching modes used on the course, we can immediately see that there seems to be a relatively even distribution of the variety of teaching modes ( 22 altogether) ticked by the respondents, resulting in a somewhat linear receding funnel shape in both figures - for in-person and online course implementation. The selection process for the questions which would target the relevant points of the research resulted in another methodological consideration. Specifically in reference to the first question, the list of possible modes of instruction (featuring a mixture of broad approaches, specific strategies and modes of interaction), with some of them being subject to overlap in reference to their implementation, represented a challenge. However, for the purposes of the present research scope, the list was selected on the basis of the instruction modes most frequently used in the in-person execution of the lessons (as recorded by the instructors who are also the co-authors of the present article). These were applied to the online mode and subsequently warranted the comparative study.

All the proposed teaching modes have been ticked at least once, with the category of workshops tailing the line in both groups of respondents (with as few as 2 votes for in-person and 3 for online instruction, corresponding to $14 \%$ and $9 \%$, respectively), while the top categories for the two groups differed as the in-person group opted for pairwork and the online group for groupwork, with $100 \%$ participation in both instances, relating to 14 and 35 ticks, respectively.

The second and the third top answers were the same in both groups, referring to formal lecture and question and answer modes of teaching. The results for the rest of the categories were featured in a somewhat comparable capacity, with only slight differences in the percentage of votes received. There were but a few exceptions. At a closer look we can notice that the in-person teaching was characterized more by in-class reading and student presentations (with $71 \%$ of votes each), while the online mode leaned more towards the use of films/videos/audios ( $89 \%$ of votes) and visualization ( $77 \%$ of votes). A comparative look shows that in the online group, in-class reading and student presentations received 54\% and 17\%, respectively, while the values for films/videos/audios and visualization in the in-person group were at $57 \%$ and $36 \%$, respectively (cf. Tables 1 and 2 in Appendices 1 and 2 for more details on the figures relating to individual categories), thus pushing these categories lower on the axis in comparison with the other group.

The results for the rest of the first set of questions again show very similar values for both groups. The questions that stand out are those in the second and third quadrants (cf. Figure 2 below), specifically the one relating to students' motivation and interest during the course (in the second quadrant) and the one on the training course meeting the respondents' expectations (in the third quadrant).

In the former we notice that motivation levels were somewhat higher in the online group, which might be a bit surprising in the context of the online switch being so unexpected and resulting in a number of issues, personal (ensuring access to the technological equipment, handling resources, setting boundaries between domestic life and school work, and similar) as well as academic (balancing home and school life, time management, mustering motivation to study, and the like; cf. also Figure 3 below). On the other hand, the slightly higher figure in 


\begin{tabular}{|c|c|}
\hline In-Person ODA Instruction & Online ODA Instruction \\
\hline$(\mathrm{n}=14)$ & $(\mathrm{n}=35)$ \\
\hline \multicolumn{2}{|c|}{ Which teaching modes were used on the course? Tick all options that apply. } \\
\hline 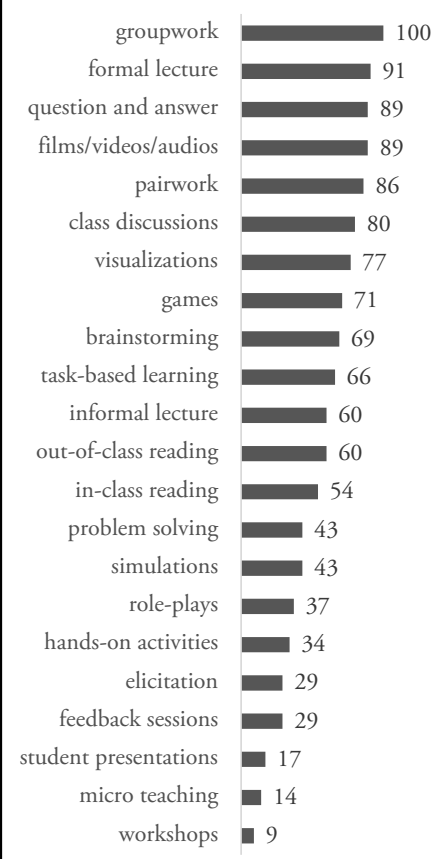 & \begin{tabular}{|r|r} 
pairwork & 100 \\
formal lecture & \\
\cline { 2 - 2 } question and answer & 93 \\
groupwork & 93 \\
class discussions & 93 \\
games & 86 \\
in-class reading & 71 \\
student presentations & 71 \\
brainstorming & 71 \\
task-based learning & 71 \\
informal lecture & 64 \\
out-of-class reading & 57 \\
hands-on activities & 57 \\
problem solving & 57 \\
films/videos/audios & 57 \\
simulations & 43 \\
elicitation & 36 \\
role-plays & 36 \\
visualizations & 36 \\
feedback sessions & 21 \\
micro teaching & 21 \\
workshops & 14
\end{tabular} \\
\hline
\end{tabular}

FIGURE 1. Comparative presentation of the results for question 1 on the use of teaching modes.

favour of the emergency online mode might make sense as the "COVID-19 generations" of students were highly appreciative of the fact that they were able to complete their university courses at all, regardless of the mode of instruction.

In the latter case, a higher percentage of respondents felt their course expectations were met in the online mode, which, again, might tie back into the unusual aspects of the COVID-19 lockdown mode and the level of maturity on the part of the students, which also translated into the slight difference in satisfaction with the online course (cf. Figure 4 below).

At this point, we can conclude that the overall student satisfaction with the course was at appropriate levels in both modes of instruction, in-person and online. It is evident from the research results that the instructors' investment of time and energy into redesigning the course for online instruction was effective and well appreciated. In addition, with the research results being very similar for both online and in-person instruction, the students' attitudes towards the two modes show a high level of adaptability and flexibility, albeit with the students' minds set on the fact that this was a temporary solution, rather than a permanent one. 


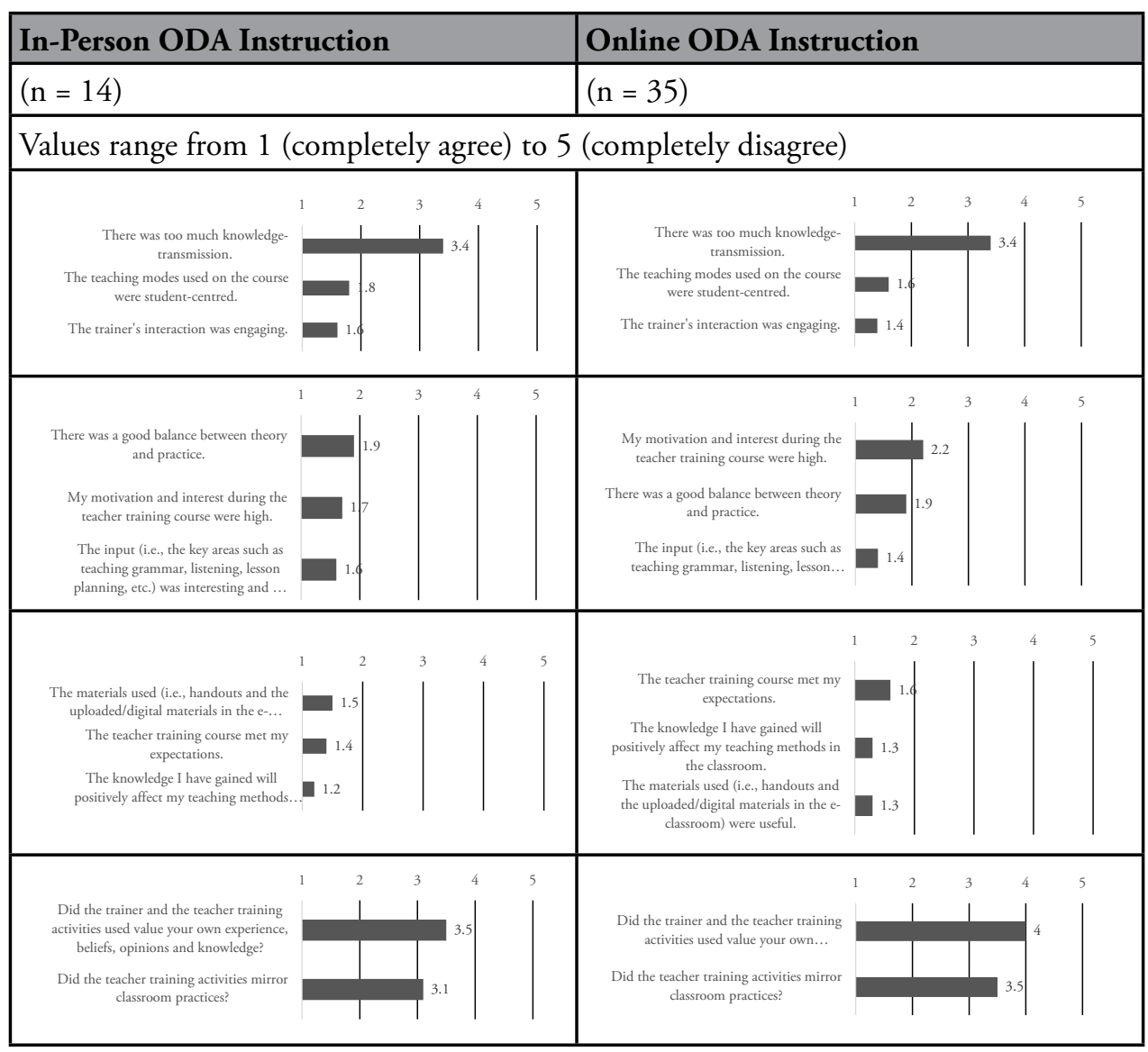

FIGURE 2. Comparative presentation of the results for questions 2-12.

As pointed out in chapter 5 on the methods used in this study, the second survey, targeting the online ODA instruction, consisted of additional 17 questions. The results for this second part of the survey are presented in Figures 3-5 below.

The first six questions (cf. Figure 3) focused on the issues that the students faced in the online mode. They sought to address the social (ability of participants to engage affectively with a community and develop interpersonal relationships), cognitive (construct meaning through sustained reflection and communication) and teaching presence (design, facilitation and direction of social and cognitive processes), identified as the crucial elements for 'a successful higher education experience' in a computer-based environment (Garrison, Anderson, and Archer 2000, 87, as cited in Carrillo and Flores 2020), the synthesis of which leads to teaching and learning impact. With a solid majority of $71 \%$ and $69 \%$, respectively, motivation to do schoolwork and observing boundaries between home and school topped the list of issues they faced. At the bottom of the list, we find problems finding a quiet space to study, at a mere $20 \%$. There was no option for them to select 'I didn't experience any problems', which presumes the respondents all experienced some sort of issues. The decision not to include the latter was made 
by the authors (who are also course instructors) on the basis of in-class discussions, where all participants expressed at least some concerns related to the online switch. However, in the subsequent studies this option should be added to ensure a higher level of respondent autonomy and objectivity with regard to the results.

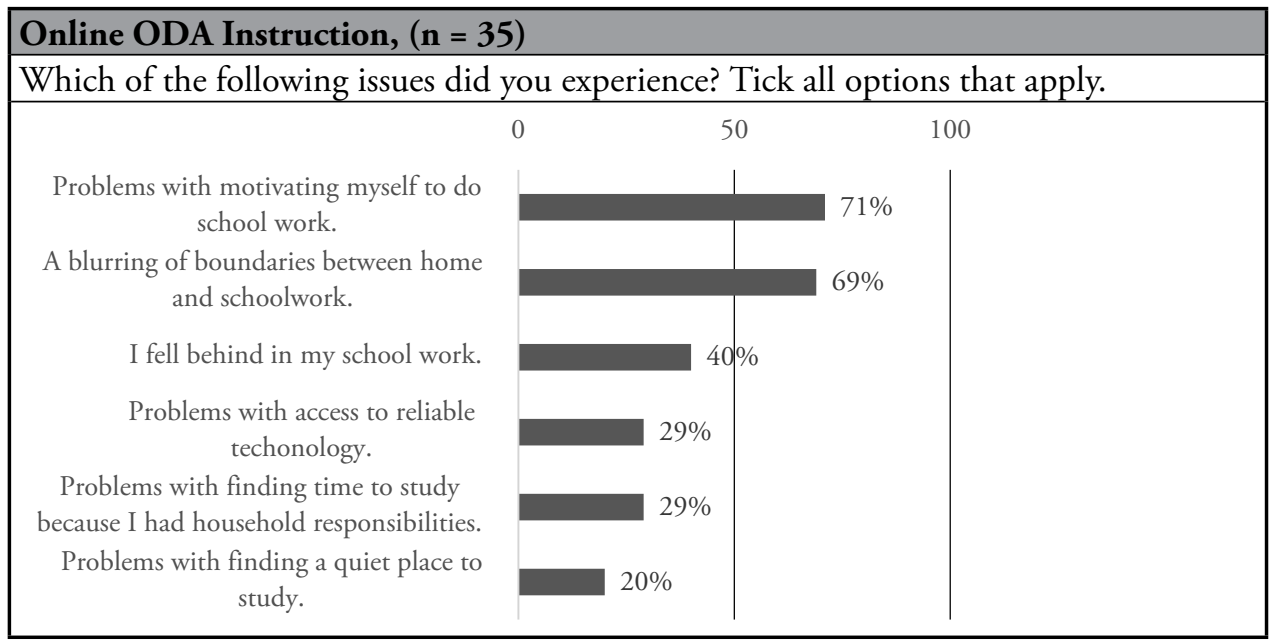

Figure 3. Results for the issues experienced in the online mode.

The next set of questions was related to the level of satisfaction with the online delivery mode, focusing on the trainees' cognitive presence (cf. Figure 4 below). The results for these show that a slight majority (54\%) agreed that both modes - online and in-person - were equally effective, in addition to $20 \%$ of respondents assessing they had actually learnt more in the online mode compared to the in-person teaching. In combination, a positive attitude towards the online mode can be registered in $74 \%$ of responses. A little over a quarter of respondents (26\%), however, felt the online mode was less effective than the in-person instruction. Similar results with regard to the complex environment at home have been recorded in previous studies on the topic of the online learning, teaching and teacher training (cf., for instance, Zhang et al. 2020, as cited in Carrillo and Flores 2020).

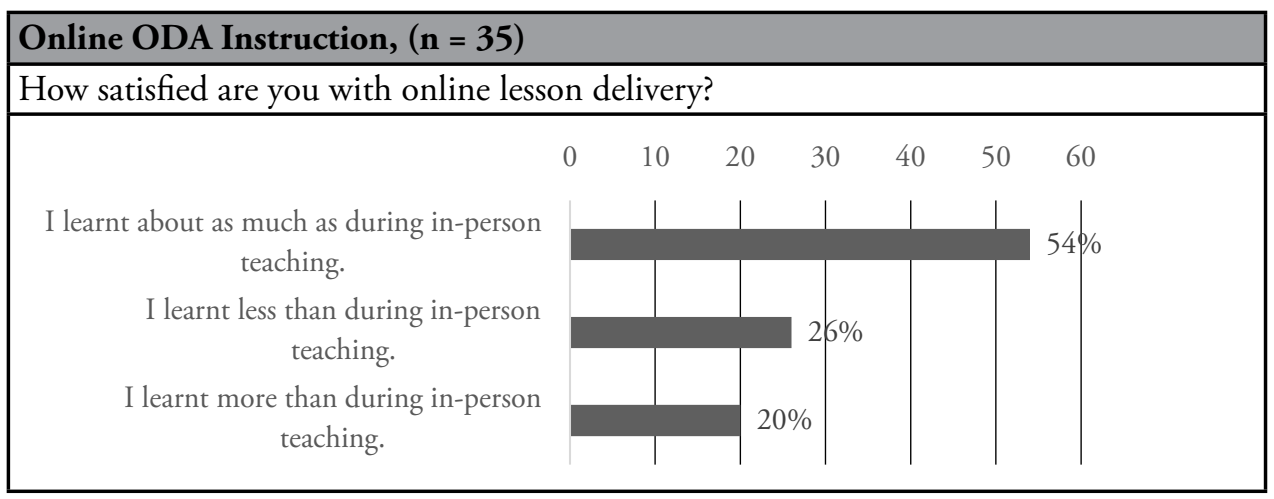

FiguRE 4. Results for the level of satisfaction with online lesson delivery. 
The results presented in Figure 4 above could be combined with those in Figure 5 below, with a focus on the teaching presence. They both refer to the respondents' impression of the online teaching mode as an alternative to in-person teaching. Overall their sentiments predominantly lean towards positive attitudes, although the online mode should not be used exclusively or permanently, but rather in combination with the in-person mode, which was reflected in the $43 \%$ share of the responses. The main arguments in support of their position can be found in Figure 6 below, focusing on the social presence, where the highest values are assigned to the students' inability to interact with their classmates (value at 77\%) and missing the energy of the classroom (at 69\%) in the online mode.

\section{Online ODA Instruction, $(\mathrm{n}=35)$}

\section{Choose the most appropriate option.}

What is your general impression of online teaching and learning?

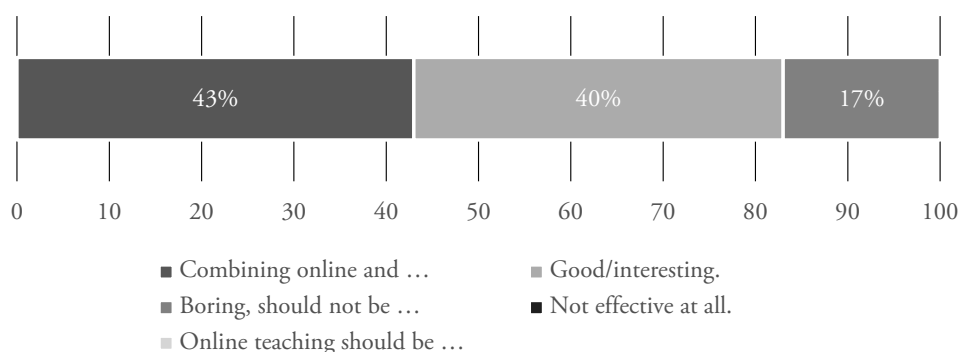

FigURE 5. Results for the general impression of the online teaching mode.

\section{Online ODA Instruction, $(\mathbf{n}=35)$}

What did you miss most during the online teaching mode? Tick all options that apply.

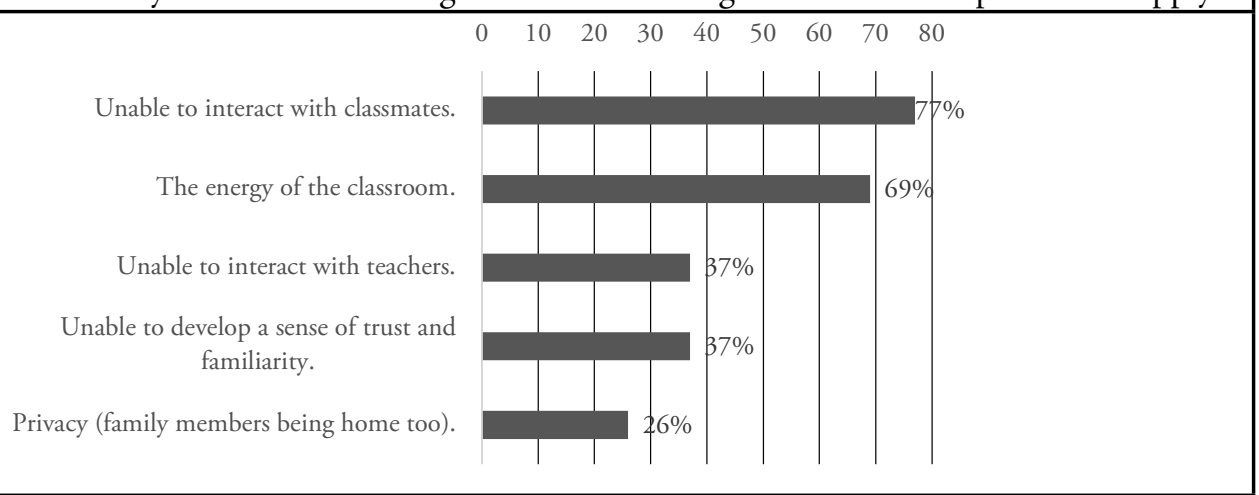

Figure 6. Results for things missed in the online mode.

The results presented in Figure 7 refer to the respondents' overall impression of their confidence levels should they have to teach in the online mode in the future, and how useful they found the online video observations of recorded lessons in this context. The latter were conducted in the Zoom environment, with pre-recorded in-person teaching sessions playing while the students were performing their specific, pre-assigned observation tasks. Immediately following the 
viewing of the recording was a group discussion of the students' results of their individual tasks. The online observations were modelled in a manner that mimicked the in-person observations, usually conducted in a physical school environment. However, due to the parameters described above, certain differences in the observation experience were expected, specifically those relating to effectiveness in relation to how well-prepared the students felt for teaching in online mode afterwards.

Slightly less than half the respondents (43\%) felt well-prepared to tackle the online teaching mode, $17 \%$ felt very well-prepared, while as many as $37 \%$ were unsure about it. The rest, amounting to a mere 3\%, felt not very well-prepared or not prepared at all. Slightly less than half the respondents (49\%) found the online observation sessions useful to some extent, while only $29 \%$ found them very useful, leaving $17 \%$ doubting their effectiveness. The rest, amounting to merely $5 \%$, were not sure or didn't find them useful at all.

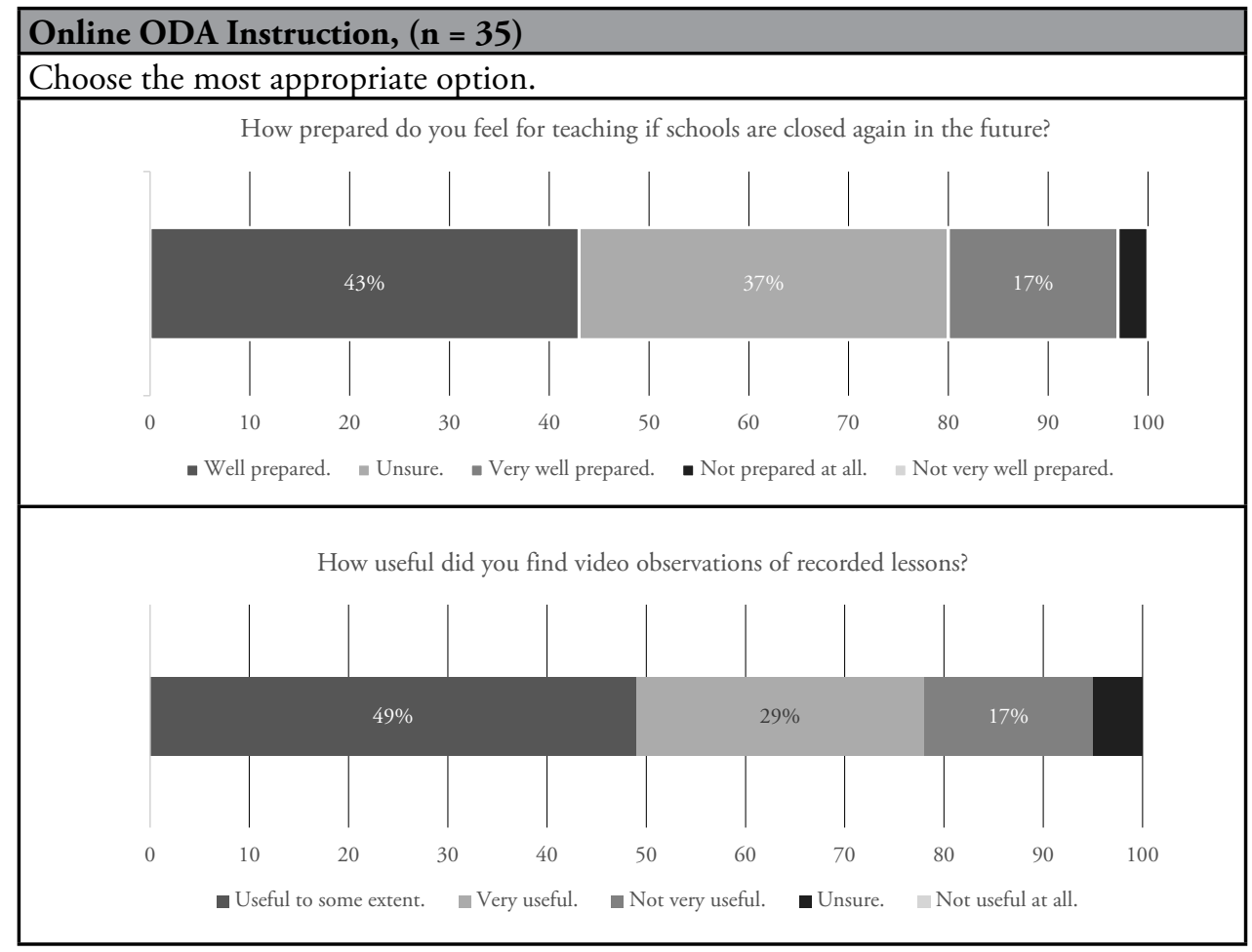

FiguRE 7. Results for preparedness for online teaching and usefulness of online observations.

Interestingly enough, the recorded success rate is therefore above $50 \%$ for both topics, when we combine the figures for well-prepared and very well-prepared for online teaching (amounting to 60\%), with the possibility of the 37\% for unsure being interpreted as a consequence of the respondents' inexperience and low self-esteem. In the latter case, the combined figures for being at least somewhat confident to teach online would rise to $97 \%$, which is quite an achievement. 
As far as the last question on online observations is concerned, a combination of values for very useful and useful to some extent amounts to $78 \%$ of respondents believing in the effectiveness of online lesson observations, at least to a certain extent. The rest (22\%), however, found them not very useful (17\%) or not useful at all (5\%). The share of respondents here is not negligible, though, warranting a revision of this section of the online teacher-training. At the same time, with value at $22 \%$, it points towards the students' dissatisfaction with the observation part of teacher-training being conducted online, and offers a partially affirmative reply to the research question number 3 , thus suggesting a return to more traditional ways on this particular segment of the teacher-training program development. Some of the dissatisfaction might also have been due to the technical difficulties involved in the implementation of the observations, as Zoom users often experience screen freezes, audio or video lags and other issues. Prior studies have recorded similar sentiments of dissatisfaction with reference to poor online teaching infrastructure and the information gap (cf. for instance Zhang et al. 2020, as cited in Carrillo and Flores 2020).

As pointed out in chapter 2, teacher-trainees are believed and expected to develop experiential knowledge by teaching or observing lessons and relating them to their experience, thus enabling a 'reflective cycle' which contributes to continuous improvement and development (Ur 1996, 5). According to Ling $(2017,562)$,

[as] teacher education is an iterative and complex process that needs to look 'backwards, forwards, inside-out and outside-in' to respond to the evolving needs of a world that is 'moving, blurring and shifting' [...], acknowledging and addressing the current and changing exceptional circumstances that teachers and students are experiencing in these unprecedented times are necessary and would provide valuable information to continue informing future online practices. (as cited in Carrillo and Flores 2020)

\section{Conclusions}

In reference to research question number 1 on the challenges related to online teacher-training and 'e-practicum', we can thus conclude that the respondents feel generally satisfied with the online implementation of this part of teacher-training, with some reservations about this sort of emergency solution, although with the understanding that this was a temporary rather than permanent measure. The challenges cited in the research results point mostly towards the problems with managing the sudden blend of domestic and academic environments, in addition to handling the issues related to resources (technological, financial, and other), while simultaneously maintaining the expected levels of motivation and balancing numerous academic, social, physical and other activities.

In response to the second research question on how to handle teacher-training when the reflective model is no longer applicable, only a quarter of respondents felt the currently implemented online model was somewhat ineffective in preparing them for their future teaching profession. The rest were, at least to a certain extent, confident that the online mode is efficient and ensures a successful transfer of knowledge.

On the question of the general impression of the online teaching mode, almost half (43\%) of the respondents felt that the combination of online and in-person modes was the most 
effective, and $40 \%$ found the online mode good/interesting, which could be interpreted as a combined value of $83 \%$ finding the online mode at least acceptable, if not even preferable. Only $17 \%$ found it boring, for instance, thus offering a valuable insight into the possible response to research question number 3 .

However, these results do not necessarily translate into the respondents being pleased with the online mode to the extent where they would choose it over the in-person one. On the basis of a more comprehensive review of all the answers obtained in the research, we can draw a general conclusion that the imposed online teaching mode did to a certain degree herald a return to a more traditional way of teaching the university-based teacher preparation courses, as it triggered a number of personal, technical and academic issues. However, at the same time, the results also point towards a favourable attitude to the online mode, as the respondents felt they had learnt as much as during in-person instruction, thus answering research question number 5 affirmatively. This finding is further strengthened with the online mode receiving a higher value than the in-person mode on motivation levels as well as on meeting course expectations. In accordance with the latter, and in answer to research question number 4, we could therefore determine that, within the context of the current emergency switch to online instruction, the desired levels of learner engagement and outcomes have been achieved.

As the online mode of instruction might persist in the future, at various levels and ranges, a need for further investigation arises, one with a broader scope in terms of the number of respondents, variety of questions, and other possible aspects, subject to a comparative study on the effectiveness of the two modes of instruction - in-person and online - in the teacher-training programs. As pointed out by Hodges et al. (2020; as cited in Carrillo and Flores 2020), "it is essential to go beyond emergency online practices and develop quality online teaching and learning that result from careful instructional design and planning." The current study emphasizes the interactive nature of the learning-teaching process, where "an effective online teaching and learning is subject to the development of a student presence that enhances supportive and productive interactions that mediate the learning process across the presences" (Hodges et al. 2020, as cited in Carrillo and Flores 2020).

\section{References}

Akbari, Ramin. 2007. "Reflections on Reflection: A Critical Appraisal of Reflective Practices in L2 Teacher Education.” System 35 (2): 192-207. https://doi.org/10.1016/j.system.2006.12.008.

Balloch, Fiona. 1996. Teacher Development Resource Book. Folkestone: English Experience.

Borg, Simon. 2006. Teacher Cognition and Language Education: Research and Practice. London: Continuum.

—. 2009. "Language Teacher Cognition." In The Cambridge Guide to Second Language Teacher Education, edited by Anne Burns, and Jack C. Richards, 163-71. Cambridge: Cambridge University Press.

Burns, Anne, and Jack C. Richards. 2009. "Introduction: Second Language Teacher Education.” In The Cambridge Guide to Second Language Teacher Education, edited by Anne Burns and Jack C. Richards, 1-8. Cambridge: Cambridge University Press.

Carrillo, Carmen, and Maria Assunção Flores. 2020. "COVID-19 and Teacher Education: A Literature Review of Online Teaching and Learning Practices.” European Journal of Teacher Education 43 (4): 466-87. https://doi.org/10.1080/02619768.2020.1821184. 
Chaves, Orlando, and Maria Eugenia Guapacha. 2016. "An Eclectic Professional Development Proposal for English Language Teachers.” PROFILE Issues in Teachers' Professional Development 18 (1): 71-96. https://doi.org/10.15446/profile.v18n1.49946.

Colomer, Jordi, Maria Pallisera, Judit Fullana, Marc Pérez Burriel, Rosario Fernández. 2013. "Reflective Learning in Higher Education: A Comparative Analysis." Procedia - Social and Behavioral Sciences 93 (2013): 364-70. https://doi.org/10.1016/j.sbspro.2013.09.204.

Cornford, Ian R. 2002. "Reflective Teaching: Empirical Research Findings and Some Implications for Teacher Education." Journal of Vocational Education and Training 54 (2): 219-36. https:// doi.org/10.1080/13636820200200196.

Dufeu, Bernard. 1994. Teaching Myself. Oxford: Oxford University Press.

Dymoke, Sue, and Jennifer Harrison, eds. 2008. Reflective Teaching and Learning. London: SAGE Publications.

Freeman, Donald, and Steve Cornwell, eds. 1993. New Ways in Teacher Education. Alexandria: TESOL.

Gebhard, Jerry G. 2009. "The Practicum.” In The Cambridge Guide to Second Language Teacher Education, edited by Anne Burns and Jack C. Richards, 250-58. Cambridge: Cambridge University Press.

Gebhard, Jerry G., and Robert Oprandy. 1999. Language Teaching Awareness: A Guide to Exploring Beliefs and Practices. Cambridge: Cambridge University Press.

Griffiths, Vivienne. 2000. “The Reflective Dimension in Teacher Education.” International Journal of Educational Research 33 (5): 539-55. https://doi.org/10.1016/S0883-0355(00)00033-1.

James, Peter. 2001. Teachers in Action: Tasks for In-Service Language Teacher Education and Development. Cambridge: Cambridge University Press.

Kidd, Warren, and Jean Murray. 2020. "The Covid-19 Pandemic and Its Effects on Teacher Education in England: How Teacher Educators Moved Practicum Learning Online." European Journal of Teacher Education 43 (4): 542-58. https://doi.org/10.1080/02619768.2020.1820480.

Krek, Milan. 2021. "Ali smo res imeli v Sloveniji najdlje zaprte šole med državami članicami EU in zakaj smo jih imeli zaprte?” Portal Plus, May 31, 2021. https://www.portalplus.si/4366/o-najdlje-zaprtih-solah/.

Krosnick, Jon A., Allyson L. Holbrook, Matthew K. Berent, Richard T. Carson, W. Michael Hanemann, Raymond J. Kopp, Robert Cameron Mitchell, Stanley Presser, Paul A. Ruud, V. Kerry Smith, Wendy R. Moody, Melanie C. Green,and Michael Conaway. 2002. "The Impact of 'No Opinion' Response Options on Data Quality. Non-Attitude Reduction or an Invitation to Satisfice?" Public Opinion Quarterly 66: 371-403. http://www.jstor.org/stable/3078768.

Kuit, Judith. A., Gill Reay, and Richard Freeman. 2001. "Experiences of Reflective Teaching." Active Learning in Higher Education 2: 128-42. https://doi.org/10.1177/1469787401002002004.

Kulas, John T., Alicia A. Stachowski, and Brad A. Haynes. 2008. "Middle Response Functioning in Likert-Responses to Personality Items.” Journal of Business and Psychology 22 (3): 251-59. https:// doi.org/10.1007/s10869-008-9064-2.

—. 2009. "Middle Category Endorsement in Odd-Numbered Likert Response Scales: Associated Item Characteristics, Cognitive Demands, and Preferred Meanings." Journal of Research in Personality 43 (3): 489-93. https://doi.org/10.1016/j.jrp.2008.12.005.

Kumaravadivelu, B. 1999. "Theorising Practice, Practising Theory: The Role of Critical Classroom Observation." In Theory in Language Teacher Education, edited by Hugh Trappes-Lomax, and Ian McGrath, 33-45. Harlow: Longman.

Kuswandono, Paulus. 2012. "Reflective Practices for Teacher Education." Language and Language Teaching Journal 15 (1): 149-62. https://doi.org/10.24071/ltt.2012.150102.

Lupinski, Kirsten, Patricia Jenkins, Audrey Beard, and LaTasha Jones. 2012. "Reflective Practice in Teacher Education Programs at a HBCU." Educational Foundations 26 (3-4): 81-92.

Malderez, Angi, and Caroline Bodoczky. 1999. Mentor Courses: A Resource Book for Trainer-Trainers. Cambridge: Cambridge University Press.

Malderez, Angi, and Martin Wedell. 2007. Teaching Teachers: Processes and Practices. London: Continuum. Mathew, Priya, Prasanth Mathew, and Prince, J. Peechattu. 2017. "Reflective Practices: A Means to Teacher Development." Asia Pacific Journal of Contemporary Education and Communication Technology 3 (1): $126-31$. 
Medgyes, Peter, and Angi Malderez, eds. 1996. Changing Perspectives in Teacher Education. Oxford: Heinemann.

Moon, Jennifer A. 2004. A Handbook of Reflective and Experiential Learning: Theory and Practice. London: Routledge Falmer.

Nunan, David, and Clarice Lamb. 1996. The Self-Directed Teacher: Managing the Learning Process. Cambridge: Cambridge University Press.

Parrott, Martin. 1993. Tasks for Language Teachers. Cambridge: Cambridge University Press.

Richards, Jack C. 1998. Beyond Training: Perspectives on Language Teacher Education. Cambridge: Cambridge University Press.

Ritchie, Hannah, Edouard Mathieu, Lucas Rodés-Guirao, Cameron Appel, Charlie Giattino, Esteban Ortiz-Ospina, Joe Hasell, Bobbie Macdonald, Diana Beltekian, and Max Roser. 2020. "Coronavirus Pandemic (COVID-19).” Our World in Data. https://ourworldindata.org/coronavirus.

Roberts, Jon. 1998. Language Teacher Education. London: Arnold.

Russell, Tom. 2005. “Can Reflective Practice Be Taught?” Reflective Practice 6 (2): 199-204. https:// doi.org/10.1080/14623940500105833.

Sellars, Maura. 2012. "Teachers and Change: The Role of Reflective Practice." Procedia - Social and Behavioral Sciences 55: 461-69. https://doi.org/10.1016/j.sbspro.2012.09.525.

Skela, Janez. 2019. “A Journey Through the Landscapes of Language Education.” In Challenging Boundaries in Language Education, edited by Achilleas Kostoulas, 15-32. Cham: Springer.

Tanner, Rosie, and Catherine Green. 1998. Tasks for Teacher Education: A Reflective Approach. Trainer's Book. Harlow: Longman.

Thaine, Craig. 2010. Teacher Training Essentials: Workshops for Professional Development. Cambridge: Cambridge University Press.

Trappes-Lomax, Hugh, and Ian McGrath, eds. 1999. Theory in Language Teacher Education. Harlow: Longman.

Ur, Penny. 1996. A Course in Language Teaching: Practice and Theory. Cambridge: Cambridge University Press.

Wallace, Michael J. 1991. Training Foreign Language Teachers: A Reflective Approach. Cambridge: Cambridge University Press.

—. 1999. “The Reflective Model Revisited.” In Theory in Language Teacher Education, edited by Hugh Trappes-Lomax, and Ian McGrath, 179-89. Harlow: Longman in association with the British Council.

Ward, John R., and Suzanne McCotter. 2004. "Reflection as a Visible Outcome for Preservice Teachers." Teaching and Teacher Education 20 (3): 243-57. https://doi.org/10.1016/j.tate.2004.02.004.

Woodward, Tessa. 1991. Models and Metaphors in Language Teacher Training. Cambridge: Cambridge University Press.

-. 1992. Ways of Training: Recipes for Teacher Training. Harlow: Longman.

Wright, Tony, and Rod Bolitho. 2007. Trainer Development. Milton Keynes: Lightning Source UK. 


\section{Appendix 1}

TABLE I. Summary of survey results for in-person teaching.

\begin{tabular}{|c|c|c|c|c|c|c|c|c|}
\hline \multirow[t]{3}{*}{ Q1 } & \multicolumn{8}{|c|}{ Which teaching modes were used on the course? Tick all options that apply. } \\
\hline & \multirow[t]{2}{*}{ Sub-questions } & \multicolumn{5}{|c|}{ Units } & \multicolumn{2}{|c|}{ Indications } \\
\hline & & Freq. & Valid & $\%$ - Valid & $\begin{array}{c}\text { Corre- } \\
\text { sponding }\end{array}$ & $\begin{array}{c}\% \text { - Corre- } \\
\text { sponding }\end{array}$ & Freq. & $\%$ \\
\hline Q1a & formal lecture & 13 & 14 & $93 \%$ & 14 & $93 \%$ & 13 & $7 \%$ \\
\hline Q1b & informal lecture & 9 & 14 & $64 \%$ & 14 & $64 \%$ & 9 & $5 \%$ \\
\hline Q1c & question and answer & 13 & 14 & $93 \%$ & 14 & $93 \%$ & 13 & $7 \%$ \\
\hline Q1d & pairwork & 14 & 14 & $100 \%$ & 14 & $100 \%$ & 14 & $7 \%$ \\
\hline Q1e & groupwork & 13 & 14 & $93 \%$ & 14 & $93 \%$ & 13 & $7 \%$ \\
\hline Q1f & in-class reading & 10 & 14 & $71 \%$ & 14 & $71 \%$ & 10 & $5 \%$ \\
\hline Q1g & out-of-class reading & 8 & 14 & $57 \%$ & 14 & $57 \%$ & 8 & $4 \%$ \\
\hline Q1h & student presentations & 10 & 14 & $71 \%$ & 14 & $71 \%$ & 10 & $5 \%$ \\
\hline Q1i & class discussions & 12 & 14 & $86 \%$ & 14 & $86 \%$ & 12 & $6 \%$ \\
\hline Q1j & hands-on activities & 8 & 14 & $57 \%$ & 14 & $57 \%$ & 8 & $4 \%$ \\
\hline Q1k & brainstorming & 10 & 14 & $71 \%$ & 14 & $71 \%$ & 10 & $5 \%$ \\
\hline Q11 & elicitation & 5 & 14 & $36 \%$ & 14 & $36 \%$ & 5 & $3 \%$ \\
\hline Q1m & feedback sessions & 3 & 14 & $21 \%$ & 14 & $21 \%$ & 3 & $2 \%$ \\
\hline Q1n & games & 12 & 14 & $86 \%$ & 14 & $86 \%$ & 12 & $6 \%$ \\
\hline Q10 & workshops & 2 & 14 & $14 \%$ & 14 & $14 \%$ & 2 & $1 \%$ \\
\hline Q1p & task-based learning & 10 & 14 & $71 \%$ & 14 & $71 \%$ & 10 & $5 \%$ \\
\hline Q1q & problem solving & 8 & 14 & $57 \%$ & 14 & $57 \%$ & 8 & $4 \%$ \\
\hline Q1r & micro teaching & 3 & 14 & $21 \%$ & 14 & $21 \%$ & 3 & $2 \%$ \\
\hline Q1s & simulations & 6 & 14 & $43 \%$ & 14 & $43 \%$ & 6 & $3 \%$ \\
\hline Q1t & role-plays & 5 & 14 & $36 \%$ & 14 & $36 \%$ & 5 & $3 \%$ \\
\hline Q1u & films/videos/audios & 8 & 14 & $57 \%$ & 14 & $57 \%$ & 8 & $4 \%$ \\
\hline Q1v & visualizations & 5 & 14 & $36 \%$ & 14 & $36 \%$ & 5 & $3 \%$ \\
\hline & SUM & & 14 & & 14 & & 187 & $100 \%$ \\
\hline
\end{tabular}




\section{Appendix 2}

TABLE 2. Summary of survey results for online teaching.

\begin{tabular}{|c|c|c|c|c|c|c|c|c|}
\hline \multirow[t]{3}{*}{ Q1 } & \multicolumn{8}{|c|}{ Which teaching modes were used on the course? Tick all options that apply. } \\
\hline & \multirow[t]{2}{*}{ Sub-questions } & \multicolumn{5}{|c|}{ Units } & \multicolumn{2}{|c|}{ Indications } \\
\hline & & Freq. & Valid & $\%$ - Valid & $\begin{array}{c}\text { Corre- } \\
\text { sponding }\end{array}$ & $\begin{array}{c}\% \text { - Corre- } \\
\text { sponding }\end{array}$ & Freq. & $\%$ \\
\hline Q1a & formal lecture & 32 & 35 & $91 \%$ & 45 & $71 \%$ & 32 & $7 \%$ \\
\hline Q1b & informal lecture & 21 & 35 & $60 \%$ & 45 & $47 \%$ & 21 & $5 \%$ \\
\hline Q1c & $\begin{array}{l}\text { question and } \\
\text { answer }\end{array}$ & 31 & 35 & $89 \%$ & 45 & $69 \%$ & 31 & $7 \%$ \\
\hline Q1d & pairwork & 30 & 35 & $86 \%$ & 45 & $67 \%$ & 30 & $7 \%$ \\
\hline Q1e & groupwork & 35 & 35 & $100 \%$ & 45 & $78 \%$ & 35 & $8 \%$ \\
\hline Q1f & in-class reading & 19 & 35 & $54 \%$ & 45 & $42 \%$ & 19 & $4 \%$ \\
\hline Q1g & out-of-class reading & 21 & 35 & $60 \%$ & 45 & $47 \%$ & 21 & $5 \%$ \\
\hline Q1h & $\begin{array}{l}\text { student } \\
\text { presentations }\end{array}$ & 6 & 35 & $17 \%$ & 45 & $13 \%$ & 6 & $1 \%$ \\
\hline Q1i & class discussions & 28 & 35 & $80 \%$ & 45 & $62 \%$ & 28 & $6 \%$ \\
\hline Q1j & hands-on activities & 12 & 35 & $34 \%$ & 45 & $27 \%$ & 12 & $3 \%$ \\
\hline Q1k & brainstorming & 24 & 35 & $69 \%$ & 45 & $53 \%$ & 24 & $6 \%$ \\
\hline Q11 & elicitacion & 10 & 35 & $29 \%$ & 45 & $22 \%$ & 10 & $2 \%$ \\
\hline Q1m & feedback sessions & 10 & 35 & $29 \%$ & 45 & $22 \%$ & 10 & $2 \%$ \\
\hline Q1n & games & 25 & 35 & $71 \%$ & 45 & $56 \%$ & 25 & $6 \%$ \\
\hline Q1o & workshops & 3 & 35 & $9 \%$ & 45 & $7 \%$ & 3 & $1 \%$ \\
\hline Q1p & task-based learning & 23 & 35 & $66 \%$ & 45 & $51 \%$ & 23 & $5 \%$ \\
\hline Q1q & problem solving & 15 & 35 & $43 \%$ & 45 & $33 \%$ & 15 & $3 \%$ \\
\hline Q1r & micro teaching & 5 & 35 & $14 \%$ & 45 & $11 \%$ & 5 & $1 \%$ \\
\hline Q1s & simulations & 15 & 35 & $43 \%$ & 45 & $33 \%$ & 15 & $3 \%$ \\
\hline Q1t & role-plays & 13 & 35 & $37 \%$ & 45 & $29 \%$ & 13 & $3 \%$ \\
\hline Q1u & films/videos/audios & 31 & 35 & $89 \%$ & 45 & $69 \%$ & 31 & $7 \%$ \\
\hline Q1v & visualizations & 27 & 35 & $77 \%$ & 45 & $60 \%$ & 27 & $6 \%$ \\
\hline & SUM & & 35 & & 45 & & 436 & $100 \%$ \\
\hline
\end{tabular}

